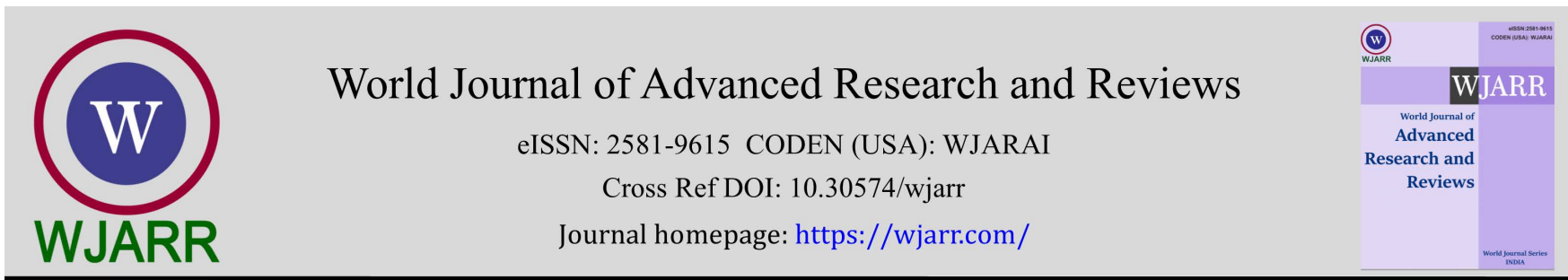

(RESEARCH ARTiClE)

Check for updates

\title{
Assessment of noise pollution and its perceived health risks on residents of Owerri Metropolis, Imo State, Nigeria
}

\author{
Mbaegbu N. Okwudili 1, Ede A. Okorie 2, ${ }^{*}$, Oparaocha R 3, Orji S. Mercy 3, Opara, E. Chinedu 4, Akpelu A. \\ Ugochinyere $^{4}$, Abonyi I. Chimezie ${ }^{2}$, Ilo C. Ifeyinwa ${ }^{2}$, Nwankwo C. Joy ${ }^{2}$ and Aronu C. Nkechi ${ }^{2}$ \\ ${ }_{1}^{1}$ Surveillance and Epidemiology Department, Nigeria Centre for Disease Control, Abuja, Nigeria. \\ 2 Department of Environmental Health Science, College of Health Sciences and Technology, Nnewi Campus, Nnamdi Azikiwe \\ University, Awka, Anambra State, Nigeria. \\ ${ }^{3}$ Department of Public Health, Federal University of Technology, Owerri, Imo State, Nigeria. \\ ${ }^{4}$ Department of Environmental Health, School of Health, Amaigbo, Owerri, Imo State, Nigeria.
}

World Journal of Advanced Research and Reviews, 2021, 10(02), 146-156

Publication history: Received on 03 April 2021; revised on 07 May 2021; accepted on 10 May 2021

Article DOI: https://doi.org/10.30574/wjarr.2021.10.2.0201

\begin{abstract}
Noise pollution is recognized as a serious health hazard to individual and society at large. In most cities, noise pollution is regarded as the most hazardous form of pollution behind air and water pollution. This study was conducted to assess the noise pollution level and its perceived health risks on the residents of Owerri Metropolis, Imo State, Nigeria. Physical measurement of noise levels was carried out at 24 different locations; three locations from 15 different political wards were selected. Each location was assessed three times at three consecutive periods (7.30-8.30a.m., 11.30 a.m.-12.30 p.m. and 3.30 - 4.30 p.m.). Thereafter, the mean reading for each location and that of each ward were calculated. Also, 900 respondents comprising adults who live and/or operate in the Council were interviewed on the perceived health risks associated with noise, using structured and standardized questionnaire. The results obtained showed that the computed mean noise level at the 24 different locations ranged from $79.4-95.8 \mathrm{~dB}$, and the cumulative for the 8 wards ranged from $87.0-91.2 \mathrm{~dB}$, all of which were significantly $(\mathrm{P}<0.05)$ above the acceptable ranges of $<80 \mathrm{~dB}$, for most of the areas surveyed, thereby rating the noise level unsatisfactory in each case as they were all within levels that can cause discomfort and pains in man. Perceived health risks enumerated by participants include; annoyance, lack of concentration, disturbed sleep, headache, hearing impairment and whistling and buzzing of the ear. The need for greater commitment by all agencies and organs involved to reduce this serious health hazard was highlighted.
\end{abstract}

Keywords: Decibel (dB); Health risks; Noise; Pollution; Sound Meter

\section{Introduction}

Noise pollution can be regarded as environmental noise and the propagation of noise may develop a harmful impact on the activity of human or animal life. According Casey et al [1], noise pollution is highest in low-income and racial minority neighborhoods due to problems associated with urban environment noise. High level of noise can contribute to health effects such as cardiovascular effects in humans and an increased incidence of coronary artery disease [2].

Menkiti and Agunwamba [3], opined that noise pollution is associated with household electricity from generator source and it is an emerging environmental degradation in many developing nations. Then, the average noise level of $97.60 \mathrm{~dB}$

\footnotetext{
${ }^{*}$ Corresponding author: Ede AO

Department of Environmental Health Science, College of Health Sciences and Technology, Nnewi Campus, Nnamdi Azikiwe

University, Awka, Anambra State, Nigeria.

Copyright (c) 2021 Author(s) retain the copyright of this article. This article is published under the terms of the Creative Commons Attribution Liscense 4.0.
} 
obtained from a carried out by Menkiti and Agunwamba in [3] exceeded the WHO value of $50 \mathrm{~dB}$ allowed for residential areas.

In most cases, noise can be defined as unwanted or extraneous sound which results from the activities of man. Anyakoha [4] stated noise is due to vibration of irregular frequency such as the ratting of a wheel on a rough road. A sound can be provided as warning when coming from fire alarm, sound as an information from a whistling tea-kettle, and enjoyment as from music in households.

In 2005, World Health Organization [5] reported that most cities in Nigeria ranked noise pollution as the third hazardous form of pollution behind air and water pollution. The common sources of environmental noise pollution include road transport systems, railway, machines and air traffic, communication, neighborhood activities, religious activities, business activities, construction and public works, manufacturing industries $[6,7]$.

Again, noise can be regarded as interferes with the ability to gather useful information from the world around us, which impairs someone's pursuit of some activities like sleeping, talking with a friend, performing some work or that merely annoys us [8]. Anomohanran et.al, [9] noted that noise is an environmental pollutant that is increasing very rapidly as a result of improvement in commercial, industrial and social activities.

The health effects of noise can occur in different forms, according to the World Health Organization [10], elderly people may suffer from cardiac problems due to noise, children to suffer much from it and can suffer permanent damage for life, because children are especially vulnerable to noise.Noise poses a serious threat to a child's physical and psychological health, including learning and behavior [11].

Cmiel et al [12], reported noise pollution as a primary cause of sleep deprivation and some certain noise levels can alter staff stress, impact job performance, induce hearing loss at high noise levels, create annoyance and cause an increased rate of burnout $[13,14,15,16]$.

For the quantification of different classes of noise, the sound level meter or sound meter is an instrument that measures sound pressure level in noise pollution studies such as industrial, aircraft and other environmental forms $[17,18]$. The unit of measurement is in decibel $(\mathrm{dB})$ which is a logarithmic mode of quantifying sound loudness, intensity and pressure. The A-weighted variety of sound wave measurement is used for the quantification of the environmental noise in $\mathrm{dB}(\mathrm{A})$ units. An increase in $10 \mathrm{~dB}$ is equivalent to doubling the loudness of sound, while increase by $6 \mathrm{~dB}$ and $3 \mathrm{~dB}$ doubles the Sound Pressure Level (SPL) and Intensity of the sound respectively [19].

The knowledge of people about noise pollution is less known than air pollution; noise pollution causes nuisance or disturbing to rest and to human activities. Modern and industrialized societies have multiplied activities source of noise that are produced by industrial and craft activities such as vehicle traffic (road, railway, and airport), leisure (discos, cinemas, dance halls) or churches or educational (kindergartens, schools).Everyone in both urban and suburban situations can live in environment with noise [7].

Noise pollution is a major environmental problem and arouses more and more reactions from the population; also it is a major cause of the deteriorating quality of life. From a scientific study conducted by Hessel [20], shows that exposure to noise may cause a number of direct adverse effects such as insomnia, auditory and extra-auditory physiological damage (mainly cardiovascular), communication difficulties and malaise [21].

Hessel, [20] and Ahmed et al. [22], stated that noise has adverse impact on the physical, social and psychological wellbeing of man and can lead to either permanent or temporary hearing loss. Acoustic trauma, tympanic membrane perforations and ossicular chain disarticulations can result from excessively loud noise/blasts. Noise induced hearing loss (type of sensorineural hearing loss) is ascribed to prolonged exposition to noise beyond the physiological recovery and reversible point of the hearing apparatus (i.e. beyond the temporary threshold shift) $[23,24,25]$. Due to inadequate regulations/legislation on noise pollution in many cities in Nigeria and other developing countries because of poor political will or this research tents to have an insight into the deleterious effect of noise on environmental life and the ecosystem. Also, it was noted the adverse effects of noise pollution are enormous and thus it becomes pertinent to measure the present level of noise in Owerri Metropolis in other to proffer some measurable solutions that can help to reduce the noise level and its associated health consequences. 


\section{Material and methods}

The research design employed in this study was a cross sectional descriptive research to assess the noise pollution and its perceived health risks on residents of Owerri Metropolis, Imo State. The studied area was Owerri Metropolis which is the capital city of Imo State. The residents are mainly civil and public servants, students, traders, artisans and farmers. The sampling technique used in this study was a cluster sampling technique. Sixty (60) respondents were randomly selected from each of the 15 political wards, given a total of (60x15) 900 study respondents which was serve as the representative of the entire population of Owerri Metropolis. The research used structured questionnaire to collect primary data from the adult residents and operators in Owerri Metropolis. There were physical measurement of noise levels at some selected places and locations in the Council, which were used to compare the universally acceptable noise levels/ranges.

Since Owerri Metropolis has 15 political wards, 8 wards were selected at random as representatives of the total wards. In random selection of the 8 wards, the researcher wrote each political ward on a piece of white paper. Each piece of paper was folded in a ball form with the surface bearing the written political ward inside. At the end, 15 white paperballs were made. The researcher shuffled them and casted them on the floor and closed eyes and picked one paper ball out of 15. The researcher then reshuffled the remaining 14 paper balls and casted them again through the same process. This process was repeated for 6 other times which led to the random selection of 8 political wards out of 15 . The 8 wards were picked at random and the order in which they were picked were as follows; Government Reserved Area (GRA), New Owerri I,Ikenegbu II, Ekeukwu, Azuzi II, Aladinma I, Azuzi I and Ikenegbu IV. Digital Sound Level Meter of $30 \mathrm{~dB}-130 \mathrm{~dB}$ was switched on for two minutes. The maximum figure/value that stabilized within the two minutes was recorded for that period as the noise level for the location.

Three places were selected for noise measurement in each ward. To locate a spot /location for noise measurement, ten spots /locations were listed and numbered each on a piece of white paper. The white pieces of papers were folded with surfaces bearing numbers inside. At the end ten white paper balls were made for each political ward.

Three locations were selected for each ward using simple random sampling. For each political ward its ten white paper balls were shuffled and casted on the floor. The researcher closed his eyes and picked anyone his hand touched first. It was opened and the location therein noted. The remaining nine were reshuffled and casted on the floor. Similarly, the researcher closed his eyes and picked anyone his hand touched first. It was opened and the location therein noted. This was repeated for three times. And through this process three locations were randomly selected. The whole exercise was conducted for seven other political wards. At the end 24(3x8) locations were randomly selected for the physical noise assessment/ measurement.

The measurement was done at three different periods in a day at each location. The periods were 7.30-8.30a.m., 11.30a.m.-12.30p.m and 3.30-4.30p.m. For each measurement to be concluded readings were taken each minute for three consecutive minutes after which the mean reading was calculated and recorded as the reading of the measurement per period. Thereafter, mean of the three measurements was calculated and recorded as the noise level for that given location for the daytime. Likewise, mean noise level for each political ward was determined accordingly. At the end of the physical noise level measurement, the results were compared with the standard acceptable noise levels/ranges following the description made by Koenigsberger, [26] and Alam, et. al, [27] (Table 1).

Table 1 Noise Quality Description for daytime.

\begin{tabular}{|l|l|}
\hline Noise level (dB) & Noise Quality Description \\
\hline $0-20$ & Excellent quality \\
\hline $21-40$ & Very good quality \\
\hline $41-60$ & Good quality \\
\hline $61-80$ & Satisfactory quality \\
\hline $81-100$ & Unsatisfactory (painful) \\
\hline $101-120$ & Hazardous quality \\
\hline$>120$ & Not allowed \\
\hline \multicolumn{2}{|l|}{ Source: Anomohanran, [17]; Koenigsberger, [26] and Alam, et. Al [27]. } \\
\hline
\end{tabular}




\subsection{Method of Data Analysis}

Analysis of data was done using Statistical Package for Social Sciences (SPSS) version 20.0 and results were presented with frequency, percentages and tables to assess the noise pollution and its perceived health risks on residents in the study area. The chi-square test was used to establish a relationship between the independent and dependent variables at $p$-value of 0.05 . The outcome enabled the researcher to accepts or reject any particular hypothesis and P-value less than 0.05 was considered statistically significant of any result obtained. The result of the physical measurement of noise level in Owerri Metropolis, Imo State was determined and compared with the expected and acceptable noise level ranges in each case.

\section{Results}

\subsection{Socio-Demographic Characteristics of the interviewees in Owerri Metropolis, Imo State}

Out of 900 subjects randomly selected from Owerri Metropolis, 55(6.1\%) were aged between 18-27 years, 64(7.1\%) for between 28-37 years, $200(22.2 \%)$ between $38-47$ years, $301(33.4 \%)$ were aged $48-57,165(18.3 \%)$ were aged 5867, while 115(12.8\%) were 68 and above years of age. Concerning gender, 349(38.8\%) were males and $551(61.2 \%)$ females. In marital status, $300(33.3 \%)$ were single, 572(63.6\%) were married, 25(2.8\%) were widows/widowers, $1(0.1 \%)$ was a divorcee and $2(0.2 \%)$ were separated.

Monthly income of respondents; 403(44.8\%) earned between N10, 000-N20, 000, 205(22.8\%) earned N21, 00 -N30, 000, 100(11.1\%) earned N31, 000 - N40, 000 while 192 (21.3\%) earned N41, 000 and above.

Their employment status showed that 200(22.2\%) were students, $29(3.2 \%)$ were unemployed, 226(25.1\%) were traders/hawkers, $410(45.6 \%)$ were civil/public servants, $10(1.1 \%)$ were farmers while $25(2.8 \%)$ were artisans. Similarly, highest educational qualification displayed that 11(1.2\%) had no formal education, 251(27.9\%) had primary education, 437(48.6\%) had secondary while 201(22.3\%) had tertiary education.

Table 2 Socio-Demographic Characteristics of the Interviewees in Owerri Metropolis, Imo State

\begin{tabular}{|l|l|}
\hline Variables & Frequency (\%) \\
\hline Age in years & \\
\hline $18-27$ & $55(6.1 \%)$ \\
\hline $28-37$ & $64(7.1 \%)$ \\
\hline $38-47$ & $200(22.2 \%)$ \\
\hline $48-57$ & $301(33.4 \%)$ \\
\hline $58-67$ & $165(18.3 \%)$ \\
\hline 68 and above & $115(12.8 \%)$ \\
\hline Gender/Sex & \\
\hline Male & $349(38.8 \%)$ \\
\hline Female & $551(61.2 \%)$ \\
\hline Marital Status & \\
\hline Single & $300(33.3 \%)$ \\
\hline Married & $572(63.6 \%)$ \\
\hline Widow/Widower & $2592.8 \%)$ \\
\hline Divorced & $1(0.1 \%)$ \\
\hline Separated & $2(0.2 \%)$ \\
\hline Average Monthly income (N) & \\
\hline $10,000-20,000$ & $403(44.8 \%)$ \\
\hline $21,000-30,000$ & $205(22.8 \%)$ \\
\hline $31,000-40,000$ & $100(11.1 \%)$ \\
\hline
\end{tabular}




\begin{tabular}{|l|l|}
\hline 41,000 and above & $192(21.3 \%)$ \\
\hline Employment Status & \\
\hline Students & $200(22.2 \%)$ \\
\hline Unemployed & $29(3.2 \%)$ \\
\hline Traders/Hawkers & $226(25.1 \%)$ \\
\hline Civil/public Servants & $410(45.6 \%)$ \\
\hline Farmers & $10(1.1 \%)$ \\
\hline Artisans & $25(2.8 \%)$ \\
\hline Highest Educational Qualification & \\
\hline No Formal Education & $11(1.2 \%)$ \\
\hline Primary & $251(27.9 \%)$ \\
\hline Secondary & $437(48.6 \%)$ \\
\hline Tertiary & $201(22.3 \%)$ \\
\hline
\end{tabular}

\subsection{Daylight Noise Level Measurement in Owerri Metropolis, Imo State}

Table 3 shows the results of daytime noise level measurements in 24 locations from 7.30am-4.30pm. In GRA, the highest noise level (99.5dB) was got at World Bank Market at period of 7.30a.m-8.30a.m while the least noise level (93.7dB) was recorded at Imo State University (IMSU) Round about.

From 11.30a.m.-2.30p.m; the highest noise level (95.7dB) was got at IMSU Round about while the least noise level (77.0dB) was recorded at Federal Medical Centre (FMC).

From 3.30p.m.-4.30p.m; the highest noise level (105.5dB) was got at FMC while the least noise level (84.70dB) was recorded at AIvan Federal College of Education (AIFCE).

In New Oweri I; morning time from 7.30a.m-8.30a.m, the highest noise level (97.0dB) was got at Imo Specialist Hospital/Port Harcourt Road Junction (Imo Sp. Hos. /PH.Rd) while the least noise level (93.0dB) was recorded at Concord Hotel Junction.

Between 11.30a.m.-2.30p.m, the highest noise level (97.0dB) was got at Imo Sp. Hos./PH. Rd. Junction while the least noise level (93.0dB) was recorded at Concord Hotel Junction. From 3.30p.m.-4.30p.m; the highest noise level (86.0dB) was got at Concord Hotel Junction while the least noise level (76.6dB) was recorded at Imo Sp. Hos./PH.Rd.

In Ikenegbu II; the noise measurements recorded as follows; from 7.30a.m to 8.30a.m, the highest noise level (99.1dB) was got at Federal Housing Estate Junction while the least noise level (90.0dB) was recorded at Ikenebgu Extension. From 11.30a.m.-2.30p.m; the highest noise level (93.3dB) was got at Federal Housing Estate Junction while the least noise level (73.5dB) was recorded at Ikenebgu Extension. From 3.30p.m.-4.30p.m; the highest noise level (93.7dB) was got at Ikenegbu Layout while the least noise level (74.60dB) was recorded at Ikenebgu Extension.

In Ekeukwu location; from 7.30a.m to 8.30a.m, the highest noise level (99.7dB) was got at AmaJk R/about while the least noise level (95.0dB) was recorded at Mbaise Rd./Douglas Rd. From 11.30a.m.-2.30p.m; the highest noise level (85.3dB) was got at Mbaise Rd./Douglas Rd while the least noise level (83.1dB) was recorded at School Rd/Douglas Rd. From 3.30p.m.-4.30 p.m; the highest noise level (99.9dB) was got at AmaJk R/about while the least noise level (83.6dB) was recorded at Mbaise Rd/Douglas Rd.

In Azuzi I location; between 7.30a.m to 8.30a.m, the highest noise level (99.2dB) was got at Bank Rd while the least noise level (95.0dB) was recorded at Orlu Rd/Bank Rd. From 11.30a.m.-2.30p.m; the highest noise level (83.5dB) was got at Orlu Rd / Bank Rd while the least noise level (79.2dB) was recorded at Bank Rd. From 3.30p.m.-4.30p.m; the highest noise level (95.9dB) was got at Control R/ about while the least noise level (86.0dB) was recorded at Bank Rd. 
Table 3 Daylight Noise Level Measurement in Owerri Metropolis, Imo State

\begin{tabular}{|c|c|c|c|c|c|c|c|c|c|}
\hline \multirow[t]{2}{*}{ S/N } & \multirow[t]{2}{*}{ Wards } & \multirow[t]{2}{*}{ Location } & \multicolumn{3}{|c|}{ Period (Daytime) } & \multirow[t]{2}{*}{$\operatorname{Mean}(\mathrm{dB})$} & \multirow{2}{*}{$\begin{array}{l}\text { Grand } \\
\text { mean for } \\
\text { ward(dB) }\end{array}$} & \multirow{2}{*}{$\begin{array}{l}\text { Acceptable } \\
\text { Range (dB) }\end{array}$} & \multirow{2}{*}{$\begin{array}{c}\text { Assessment/ } \\
\text { Description }\end{array}$} \\
\hline & & & $\begin{array}{l}\text { 7.30a.m- } \\
\text { 8.30a.m }\end{array}$ & $\begin{array}{l}\text { 11.30a.m.- } \\
\text { 2.30p.m. }\end{array}$ & $\begin{array}{l}\text { 3.30p.m.- } \\
\text { 4.30p.m. }\end{array}$ & & & & \\
\hline \multirow[t]{4}{*}{1} & \multirow[t]{4}{*}{ GRA } & AIFCE & 95.5 & 77.0 & 84.7 & 85.7 & & $30-40$ & Unsatisfactory \\
\hline & & FMC & 95.9 & 77.1 & 105.5 & 92.8 & 91.1 & $20-35$ & Unsatisfactory \\
\hline & & IMSU Round about & 93.7 & 95.7 & 94.9 & $94 \ldots 8$ & & $61-35$ & Unsatisfactory \\
\hline & & World Bank Market & 99.5 & 80.3 & 92.5 & 90.8 & & $65-70$ & Unsatisfactory \\
\hline \multirow[t]{2}{*}{2} & \multirow{2}{*}{$\begin{array}{l}\text { New Oweri } \\
\text { I }\end{array}$} & Concord Hotel Junction & 93.0 & 86.0 & 95.0 & 91.3 & & $40-60$ & Unsatisfactory \\
\hline & & Imo Sp. Hos./PH. Rd. Junction & 97.0 & 76.7 & 93.5 & 89.1 & 90.4 & $65-70$ & Unsatisfactory \\
\hline \multirow[t]{3}{*}{3} & \multirow[t]{3}{*}{ Ikenegbu II } & Ikenegbu Layout & 97.0 & 74.2 & 93.7 & 88.3 & & $25-40$ & Unsatisfactory \\
\hline & & Ikenebgu Extension & 90.0 & 73.5 & 74.6 & 79.4 & & $25-40$ & Unsatisfactory \\
\hline & & Fed. Housing Estate Junction & 99.1 & 93.5 & 87.6 & 93.4 & 87.0 & $25-40$ & Unsatisfactory \\
\hline \multirow[t]{3}{*}{4} & \multirow[t]{3}{*}{ Ekeukwu } & AmaJk R/about & 99.7 & 84.0 & 99.9 & 94.5 & & $61-75$ & Unsatisfactory \\
\hline & & Sch, Rd/Douglas Rd & 95.3 & 83.1 & 85.0 & 87.8 & & $61-75$ & Unsatisfactory \\
\hline & & Mbaise Rd./Douglas Rd & 95.0 & 85.3 & 83.6 & 88.0 & 90.1 & $61-75$ & Unsatisfactory \\
\hline \multirow[t]{3}{*}{5} & \multirow[t]{3}{*}{ Azuzi I } & Control R/ about & 96.7 & 77.8 & 95.9 & 90.1 & & $61-75$ & Unsatisfactory \\
\hline & & Orlu Rd / Bank Rd & 95.0 & 85.5 & 91.2 & 90.6 & & $25-40$ & Unsatisfactory \\
\hline & & Bank Rd & 99.2 & 79.2 & 86.0 & 88.1 & 89.6 & $20-35$ & Unsatisfactory \\
\hline \multirow[t]{3}{*}{6} & \multirow[t]{3}{*}{ Azuzi I1 } & Fire Service R/about & 99.0 & 83.3 & 85.8 & 89.4 & & $61-75$ & Unsatisfactory \\
\hline & & Lobour Street & 99.1 & 76.3 & 99.5 & 91.6 & & $25-40$ & Unsatisfactory \\
\hline & & St, Lk Hos/Mbaise Rd & 99.2 & 75.2 & 99.2 & 91.2 & 90.7 & $20-35$ & Unsatisfactory \\
\hline \multirow[t]{3}{*}{7} & \multirow[t]{3}{*}{ Aladinma I } & Aladinma Housing Estate & 99.3 & 90.9 & 74.7 & 88.3 & & $25-40$ & Unsatisfactory \\
\hline & & Aladinma, Hospital Junction & 99.9 & 90.2 & 78.1 & 89.4 & & $20-35$ & Unsatisfactory \\
\hline & & WACE Rd, Junction & 95.3 & 99.2 & 93.0 & 95.8 & 91.2 & $35-45$ & Unsatisfactory \\
\hline \multirow[t]{3}{*}{8} & \multirow{3}{*}{$\begin{array}{l}\text { Ikenegbu } \\
\text { IV }\end{array}$} & Wetheral / Oki. Rd & 94.9 & 95.5 & 81.8 & 90.7 & & $61-75$ & Unsatisfactory \\
\hline & & Cherubim Junction & 90.2 & 83.0 & 87.8 & 87.0 & & $65-70$ & Unsatisfactory \\
\hline & & MCC.Rd./Wetheral Rd. & 97.8 & 78.1 & 93.8 & 89.9 & 90.2 & $35-45$ & Unsatisfactory \\
\hline
\end{tabular}


In Azuzi I1 location; for the morning period, 7.30a.m to 8.30a.m, the highest noise level (99.2dB) was got at St, Lk Hos/Mbaise Rd while the least noise level (99.0dB) was recorded at Fire Service R/about. From 11.30a.m.-2.30p.m; the highest noise level (83.3dB) was got at Fire Service R/about while the least noise level (75.2dB) was recorded at St, Lk Hos/Mbaise Rd. From 3.30p.m.-4.30p.m; the highest noise level (99.5dB) was got at Lobour Street while the least noise level $(85.8 \mathrm{~dB})$ was recorded at Fire Service R/about.

In Aladinma I location; from 7.30a.m to 8.30a.m, the highest noise level (99.9dB) was got at Aladinma, Hospital Junction while the least noise level (95.3dB) was recorded at WACE Rd, Junction. From 11.30a.m.-2.30p.m; the highest noise level (99.2dB) was got at WACE Rd, Junction while the least noise level (90.2dB) was recorded at Aladinma, Hospital Junction. From 3.30p.m.-4.30p.m; the highest noise level (93.0dB) was got at WACE Rd, Junction while the least noise level $(74.7 \mathrm{~dB})$ was recorded at Aladinma Housing Estate.

In Ikenegbu Iv; the noise measurements recorded as follows; from 7.30a.m to 8.30a.m, the highest noise level (97.8dB) was got at MCC.Rd./Wetheral Rd while the least noise level (90.2dB) was recorded at Cherubim Junction. From 11.30a.m.-2.30p.m; the highest noise level (95.5dB) was got at Wetheral / Oki. Rd while the least noise level (78.1dB) was recorded at MCC.Rd./Wetheral Rd. From 3.30p.m.-4.30p.m; the highest noise level (93.8dB) was got at MCC.Rd./Wetheral Rd while the least noise level $(81.80 \mathrm{~dB})$ was recorded at Wetheral / Oki. Rd.

\subsection{Influence of Socio-demographic Factors on Noise Pollution in Owerri Metropolis}

Out of 900 respondents interviewed in table 4,771(85.7\%) reported that locality influences noise generation most compared to other factors, $30(3.3 \%)$ said gender/sex, $28(3.1 \%)$ said occupation/level of income of persons, 45(5.0\%) said level of education, while $5(0.6 \%)$ believed, none of the above factors were responsible.

Table 4 Influence of Socio-demographic Factors on Noise Pollution in Owerri Metropolis

\begin{tabular}{|c|c|c|c|c|c|}
\hline \multirow[t]{2}{*}{ Variables } & \multicolumn{2}{|c|}{$\begin{array}{c}\text { Frequency (\%) } \\
\text { Gender }\end{array}$} & \multirow[t]{2}{*}{ Total } & \multirow[t]{2}{*}{ P value } & \multirow[t]{2}{*}{ Chi-square } \\
\hline & $\mathbf{M}$ & $\mathbf{F}$ & & & \\
\hline Age & $10(1.1)$ & $10(1.1)$ & $20(2.2)$ & $\mathrm{P}<(0.05)$ & 1422.487 \\
\hline Locality & $380(42.2)$ & $391(43.4)$ & $771(85.7)$ & & \\
\hline Gender/Sex & $17(1 / 9)$ & $13(1.4)$ & $30(3.3)$ & & \\
\hline Occupation/income & $10(1.1)$ & $18(2.0)$ & $28(3.1)$ & & \\
\hline Level of Education & $15(1.7)$ & $30(3.3)$ & $45(5.0)$ & & \\
\hline None of the above & $0(0.0)$ & $5(0.6)$ & $5(0.6)$ & & \\
\hline Total & & & $900(100)$ & & \\
\hline
\end{tabular}

\subsection{Perceived Associated Health Risks of Noise Pollution on the Residents of Owerri Metropolis}

Table 5 showed perceived associated health risks of noise pollution on the residents of Owerri municipal council, $47(5.2 \%)$ reported disturbs my sleep, $24(2.7 \%)$ said it causes annoyance, $41(4.61 \%)$ said it causes headache, $21(2.3 \%)$ reported interference with my conversation, $36(4.0 \%)$ it disturbs while teaching or listening to my teachers, 39(4.3\%) said it makes me unable to understand speech, 31(3.4\%) said pains, $19(2.1 \%)$ said lack of concentration, $13(1.4 \%)$ said whistling and buzzing of the ear, 38(4.2\%) said hearing impairment while 591(65.7\%) reported all of the above. Then, the evaluation of perceived associated health risks of noise pollution on the residents on gender dependent, 677(75.2) said yes and 206(22.9) said no while 17(1.9) were undecided. 
Table 5 Perceived Associated Health Risks with Noise Pollution on the Residents of Owerri Metropolis.

\begin{tabular}{|l|c|c|c|c|c|}
\hline \multirow{2}{*}{ Variables } & \multicolumn{2}{|l|}{ Frequency (\%) Gender } & Total & P-value & $\begin{array}{l}\text { Chi-square } \\
\text { calculated }\end{array}$ \\
\cline { 2 - 6 } & $\mathbf{M}$ & $\mathbf{F}$ & & & P \\
\hline Causes annoyance & $21(2.3)$ & $26(2.9)$ & $24(2.7)$ & P 0.05 & $=3499.267 ;$ \\
\hline Causes headache & $14(1.6)$ & $10(1.1)$ & $41(4.6)$ & & \\
\hline Interferes with my conversation & $15(1.7)$ & $26(2.9)$ & $21(2.3)$ & & \\
\hline $\begin{array}{l}\text { Disturbs while teaching or listening } \\
\text { to my teachers }\end{array}$ & $9(1.0)$ & $12(1.3)$ & $36(4.0)$ & & \\
\hline $\begin{array}{l}\text { Makes me unable to understand } \\
\text { speech }\end{array}$ & $21(2.3)$ & $15(1.7)$ & $39(4.3)$ & & \\
\hline Pains & $19(2.1)$ & $20(2.2)$ & $31(3.4)$ & & \\
\hline Lack of concentration & $22(2.4)$ & $9(1.0)$ & $19(2.1)$ & & \\
\hline Whistling and buzzing of the ear & $10(1.1)$ & $9(1.0)$ & $13(1.4)$ & & \\
\hline Hearing impairment & $12(1.3)$ & $1(0.01)$ & $38(4.2)$ & & \\
\hline All of the above & $30(3.3)$ & $8(0.9)$ & $591(65.7)$ & & \\
\hline $\begin{array}{l}\text { Tabulated } x^{2}=18.307 ; \\
d f=11\end{array}$ & $100(11.1)$ & $491(54.6)$ & & & \\
\hline The Perceived Associated Health & & & & & \\
\hline $\begin{array}{l}\text { Risks are age and gender } \\
\text { dependent }\end{array}$ & $300(33.3)$ & $377(41.9)$ & $61(75.2)$ & & \\
\hline Yes & $100(11.1)$ & $106(11.8)$ & $206(22.9)$ & & \\
\hline No & $7(0.8)$ & $10(1.1)$ & $17(1.9)$ & & \\
\hline Undecided & & & & \\
\hline
\end{tabular}

\section{Discussion}

The findings from this study titled assessment of noise pollution and its perceived health risks on residents of Owerri Metropolis, Imo State, Nigeria, showed that the noise level in all the 24 locations were above their respective acceptable ranges when compared with the standards from Koenigsberger [26] and Alam et. al, [27], and therefore, they were rated unsatisfactory according to the standard set by Anomohanran [17].

Noise level was not steady in any of the 24 locations measured during the periods of assessment. In each location noise level reached its peak in the morning period of 7.30 -8.30 a.m., decreased at Mid-day period of 11.30a.m -12.30p.m.and increased again in the late afternoon period of 3.30-4.30p.m.This justified the claim of Schomer [28] that noise levels in the city increases during morning and evening rush hours.

This is due to gathering of people and work activities, which agreed with Ozer and Irmak [29]. Increased transportation/ traffic contributed to the noise generation at these periods corroborated [30], Alterola [31] and Lebiedowska [32]. During the morning hours, people were rushing to works and businesses, parents were taking their children to schools and there were gatherings of people in most public places which increased noise level. At mid-day periods, people had settled in their places of works and business, there was decrease in traffic and this led to reduction in noise generation. Again during the late afternoon periods, people were going home; parents were rushing to pick up their children from schools. Also Christians were attending evening religious worships, coupled with the heated environment. These no doubt increased noise generation. 
Furthermore, noise generation was found higher in some places than others in Owerri Metropolis. This agrees with Anomohanran [17] who stated that different places in Abuja, Nigeria had different noise levels, some higher than the acceptable ranges. And in this study, while Ikenegbu Extension remained the location with the least mean daytime noise level of 79.4dB, WACE Rd. Junction had the highest mean daytime noise level of 95.8dB. And Ikenegbu II had the least grand mean daytime noise level of $87.0 \mathrm{~dB}$ while Aladinma I had the highest grand mean daytime of $91.2 \mathrm{~dB}$.

From the socio-demographic view point, locality, gender/sex, occupation/level of monthly income and level of education were implicated as factors influencing noise generation in Owerri Metropolis. A good number of the residents were peasants earning an average monthly income of N10,000-N20, 000. This no doubt would make them lack the capacity to live and operate in decent, separate and noise-free environments. Gender/sex is another factor that influenced noise generation according to the result. This opinion of the interviewees confirmed the statements of Rains et al [33] that illiterate women and illiterate young adult males generate noise more than their counterparts. And they might not be knowledgeable enough on the dangers inherent in noise pollution. Low socio-demographic status leads to neighbourhood overcrowding and the associated human activities such as the indiscriminate use of loud speakers, entertainment, festivals, election campaign rallies, fireworks, etc., all these push up the noise pollution level during the evening hours. The result further confirmed WHO, [34] report on the effects of environmental noise pollution on human and animal beings. Therefore, Chi-square testing shows statistical significance difference between socio-demographic and noise pollution.

In the study areas, noise pollution was perceived to be associated with many health risks. It disturbed sleep. This is in concord with Heewagen [8] who noted that noise interferes and impairs with pursuit of some activities like sleeping. The result showed that noise pollution, causes annoyance to the people. Also Amadi [35] affirmed that noise pollution causes annoyance by interfering with conversation, mental concentration, rest and recreation.

Noise pollution also caused headache to the residents. It corroborated with work done by Ozer et al [29], who opined that noise pollution level above $80 \mathrm{~dB}$ may cause headache, rise blood pressure and sweating, and in this study mean daytime noise levels of 23 out of 24 locations measured $85 \mathrm{~dB}$ and above. Noise pollution interfered with conversation, disturbed teaching/learning, makes people unable to understand speech and caused lack of concentration to the residents of Owerri Metropolis as seen in this study. The result equally corroborated Yoshida et al [36] and WHO [30] who observed that noise pollution affect speech intelligibility by masking the intelligibility of the spoken words such that simultaneously interfering noise render speech incapable of being understood.

Noise pollution caused pains, whistling and buzzing of the ear and hearing impairment to the interviewed residents of Owerri Metropolis. Hearing impairment is a problem that develops according to EPA [37] with increasing noise levels and exposure time. Morata (2000) added that in developing countries both occupational and environmental noises constitute increasing risk factor for hearing impairment. Owerri Metropolis is a developing place where residents are exposed to noise pollution, no wonder the results.

The perceived associated health risks of noise pollution in Owerri Metropolis were both age and gender dependent. This supports WHO [34] statement that 360 million people worldwide live with disabling hearing loss, with 328 million of this member representing $91 \%$ adults and males suffer from hearing loss more than the females. This means that the more people are exposed to noise pollution with increasing age and therefore, age has a statistical significance difference with noise pollution.

The study therefore, established very dangerous noise pollution level in Owerri Metropolis of Imo State, Nigeria and ways to curtail this serious public health problem must be carefully studied and put operational to safe the residents from more hazards.

\section{Conclusion}

Based on the findings of this study, there was noise pollution in Owerri Metropolis, with noise generation higher in some places than others. The noise pollution is influenced by socio-demographic data with the perceived associated health risks. And these perceived associated health risks on residents were both age and gender dependent. More so, there was no education of the residents and operators on the dangers inherent in noise pollution which was worsened by lack of enforcement of the laws prohibiting noise pollution in Owerri Metropolis.

Since there is noise pollution in Owerri Metropolis and nobody does anything to control it. It is one of the major causes of high rates of morbidity especially cardiovascular diseases and mortality in the council. And this will increase with the perceived daily influx of people into Owerri Metropolis. 
There should be careful planning and implementation of Owerri Municipal Council master plan. Those in charge should ensure adequate control of vehicular movement and improvement in the acoustic installation of buildings. Government should educate the residents on the dangers inherent in noise pollution and enforce laws prohibiting noise pollution in Owerri Metropolis. Noise pollution prevention, control and management should be part of the educational curriculum. There should be expansion of the city to accommodate the influx of the people. Finally some tertiary institutions should be cited outside Owerri Metropolis to decongest the population.

\section{Compliance with ethical standards}

\section{Acknowledgments}

We wish to acknowledge the ward leaders, community leaders and Dean of faculties in Tertiary Institutions in Owerri Metropolis, for the immense support.

\section{Disclosure of conflict of interest}

All authors of this article report no conflicts of interest throughout the work.

\section{References}

[1] Casey JA, James P, Morello-Forsch R. Urban noise pollution is worst in poor and minority neighborhoods and segregated cities". PBS. 2017.

[2] Hoffmann Barbara, Moebus Susanne, Stang Andreas, Beck Eva-Maria, Dragano N, Möhlenkamp S, Schmermund A, Memmesheimer M, Mann K. Residence close to high traffic and prevalence of coronary heart disease. European Heart Journal. 2009; 27(22):2696-2702.

[3] Menkiti NU, Agunwamba JC. Assessment of noise pollution from electricity generators in a high-density residential area, African Journal of Science, Technology, Innovation and Development. 2015; 7(4):306 -312.

[4] Anyakaoha MW. New school physics for secondary schools. Onitsha: African First Publishers. 2007; 332-333.

[5] WHO Occupational and community noise WHO publication, WHO-OHS.www.arpapress.2/URAS-14-224guidelines-summary-htn Pdf. 2005.

[6] Michael CH, Gary LL. The relationship between highway planning and urban noise, The Proceedings of the ASCE, Urban Transportation, Chicago, Illinois. By American Society of Civil Engineers. Urban Transportation Division. 2013; 21-23.

[7] Moudon AV. Real noise from the urban environment: How ambient community noise affects health and what can be done about it. Am J Prev Med. 2009; 37:167-171.

[8] Heerwagen D. Passive and active environmental control: informing the schematic designing of buildings. New York: The McGram-Hill.2004; 501-502.

[9] Anomhanran 0, Iwegbue CMA, Oghenerhoro O, Egbai JC. Investigation of environmental noise pollution level of Abraka in Delta State, Nigeria. Trends in Applied Sciences Research. 2008; 3(4):292-297.

[10] WHO. Analysing and mapping spatial and temporal dynamics of Urban traffic noise pollution: A case study in Kahramamaras. Turkey Envirom. Monitor Assess. 2006; 142:65-72.

[11] Rosen S, Olin P. Hearing Loss and Coronary Heart Disease, Archives of Otolaryngology. 2016; 82:236.

[12] Cmiel CA, Karr DM, Gasser DM, Oliphant LM, Neveau AJ. Noise control: a nursing team's approach to sleep promotion. Am. J. Nurs. 2004; 104(2):40-48.

[13] Bayo MV, Garcia AM, Garcia A. Noise levels in an urban hospital and workers' subjective responses Arch. Environ. Health. 2015; 50:247-251.

[14] Blomkvist V, Eriksen CA, Theorell T, Ulrich R, Rasmanis G. Acoustics and psychosocial environment in intensive coronary care Occup. Environ. Med. 2015; 62.

[15] Love H. Noise exposure in the orthopaedic operating theatre: a significant health hazard. ANZ J. Surg. 2013; 73:836-838. 
[16] Zhang M, Kang J, Jiao F. A social survey on the noise impact in open-plan working environments in China Sci. Total Environ. 2012; 438:517-526.

[17] Anomohanran O. Evaluation of Environmental Noise Pollution In Abuja, The Capital City Of Nigeria. International Journal of Research and Reviews in Applied Sciences, 2013; 14(2):470-476.

[18] Anomohanran 0, Iwegbue CMA, Oghenerhoro O, Egbai OJC. Investigation of environmental noise pollution level of Abraka in Delta State, Nigeria. Trends Appl Sci Res. 2009; 3(4):292-297.

[19] Santini S, Ostermaier B, Vitaletti A. First experiences using wireless sensor networks for noise pollution monitoring. in Proceedings of the 3rd ACM Workshop on Real-World Wireless Sensor Networks (REALWSN'08); Glasgow, United Kingdom. 2008; 34-38.

[20] Hessel PA. Hearing loss among construction workers in Edmonton, Alberta, Canada. J Occup Environ Med. 2010; 42(1):57-63.

[21] Hessel PA, Sluis-Cremer GK. Hearing loss in white South African goldminers. S. Afr. Med. J. 2007; 71:364-367.

[22] Ahmed HO, Dennis JH, Badran O. Occupational noise exposure and hearing loss of workers in two plants in eastern Saudi Arabia. Ann Occup Hyg. 2011; 45(5):371-380.

[23] Cave KM, Cornish EM, Chandler DW. Blast injury of the ear: Clinical update from the global war on terror. Military Medicine. 2007; 172:726-730.

[24] Talaska AE, Schacht J. Mechanisms of noise damage of the cochlea. Audiological Medicine. 2007; 5:3-9.

[25] Henderson D, Bielefeld EC, Harris KC, Hu BH. The role of oxidative stress in noise-induced hearing loss. Ear \& Hearing. 2006; 27(1):1-19.

[26] Koenigsberger 0. Manual of tropical housing and building, part 1, climatic design. Bombay: Orient Longman. 1973; 8-12.

[27] Alam JB, Alam MJB, Rahman MM. Study on traffic noise level of Sylhet by multiple regression analysis associated with health hazards. Iran Journal of Environ. Health Sci. Eng. 2006;3(2):71-78.

[28] Schomer P. A White Paper Assessment of Noise, Annoyance, Schomer and Associate Inc Campaign. 2001; II 61821.

[29] Ozer S, Irmak MA, Hasan Y. Determination of roadside noise rduction effectiveness of Pinus Sylvester L. and populusnigra L. in Erzurum. Turkey: Environment Mont Assess. 2008; 144:191-197.

[30] WHO. Guidelines for Community Noise. Executive Summary.

[31] Alberola J, Flindell H, Bullmore J. Variability in road traffic noise level. European Commission Environmental Noise Directive 2002/49/EC off J European Communalities. 2005; 189: 12-25.

[32] Lebiedowska B. Aconstic background and transport noise in urbanized areas: A note on the relative classification of the city soundscape. Trans. Resi Part D: transport and environment. 2005; 10(4): 341-345.

[33] Rains J, Alba J, Garcia D, Hernandoz F. Noise effects of reducing traffic flow through an environmental control measures. Spanish City, Spain Appl. Acoust.2003; 64(3): 343-364.

[34] World Health Organization. Burden of disease from environmental noise. Geneva: WHO. 2011.

[35] Amadi AN. ABC of environment health. Owerri: Readon.Publishers.2011; 391-405.

[36] Yoshida T, Osada Y, Kawagudchi T, Hoshiyama Y,Yamamoto K. Effects of road traffic noise on inhabitants of Tokyo. Tokyo: Journal Sound Vib. 1997; 205: 517-522.

[37] Environmental Protection Agency EPA. Atmosphere, Noise, pollution. 